\title{
Ataxia telangiectasia mutated is essential during adult neurogenesis
}

\author{
Duane M. Allen, ${ }^{1,6}$ Henriette van Praag, ${ }^{1,6}$ Jasodhara Ray, ${ }^{1}$ Zoë Weaver, ${ }^{2}$ Christopher J. Winrow, ${ }^{1}$ \\ Todd A. Carter, ${ }^{1}$ Ray Braquet, ${ }^{3}$ Elizabeth Harrington, ${ }^{4}$ Thomas Ried, ${ }^{2}$ Kevin D. Brown, ${ }^{3}$ \\ Fred H. Gage, ${ }^{1}$ and Carrolee Barlow ${ }^{1,5}$ \\ ${ }^{1}$ The Salk Institute for Biological Studies, Laboratory of Genetics, La Jolla, California 92037, USA; ${ }^{2}$ Genetics Department, \\ Division of Clinical Sciences, National Cancer Institute, National Institutes of Health, Bethesda, Maryland 20892, USA; \\ ${ }^{3}$ Department of Biochemistry and Molecular Biology and The Stanley S. Scott Cancer Center, Louisiana State University \\ Medical Center, New Orleans, Louisiana 70112, USA; ${ }^{4}$ Laboratory of Molecular Oncology, Massachusetts General Hospital \\ Cancer Center, Charlestown, Massachusetts 01029, USA
}

\begin{abstract}
Ataxia telangiectasia (A-T) is an autosomal recessive disease characterized by normal brain development followed by progressive neurodegeneration. The gene mutated in A-T (ATM) is a serine protein kinase implicated in cell cycle regulation and DNA repair. The role of ATM in the brain and the consequences of its loss on neuronal survival remain unclear. We studied the role of ATM in adult neural progenitor cells in vivo and in vitro to define the role of ATM in dividing and postmitotic neural cells from Atm-deficient $\left(\mathrm{Atm}^{-/-}\right)$ mice in a physiologic context. We demonstrate that ATM is an abundant protein in dividing neural progenitor cells but is markedly down-regulated as cells differentiate. In the absence of ATM, neural progenitor cells of the dentate gyrus show abnormally high rates of proliferation and genomic instability. $\mathrm{Atm}^{-/-}$cells in vivo, and in cell culture, show a blunted response to environmental stimuli that promote neural progenitor cell proliferation, survival, and differentiation along a neuronal lineage. This study defines a role for ATM during the process of neurogenesis, demonstrates that ATM is required for normal cell fate determination and neuronal survival both in vitro and in vivo, and points to a mechanism for neuronal cell loss in progressive neurodegenerative diseases.
\end{abstract}

[Key Words: Neural progenitor; DNA repair; neuron; oligodendrocyte; astrocyte; running]

Received November 22, 2000; revised version accepted January 8, 2001.

Ataxia telangiectasia (A-T) is an autosomal recessive disorder presenting as an extensive combination of clinical defects (Gatti 1998). The hallmark of the disease is progressive neuromotor dysfunction culminating in global neurological compromise. Several neuropathological processes occur, beginning initially as gradual cerebellar cortical atrophy. Eventually, all areas of the brain are affected. Additional features include immune deficiency, retarded somatic growth, premature aging, gonadal dysgenesis, extreme predisposition to lymphoreticular malignancies, and acute sensitivity to ionizing radiation.

The gene mutated in A-T, ATM, was identified by positional cloning (Savitsky 1995a,b), and both sequence inspection of the ATM gene product and recent biochemical analyses clearly established that ATM is a protein kinase (for reviews, see Rotman and Shiloh 1998; Brown et al. 1999; Wang 2000). Cells from A-T patients and $\mathrm{Atm}^{-1-}$ mice are radiosensitive and are defective in a

${ }^{5}$ Corresponding author.

E-MAIL barlow@salk.edu; FAX (858) 558-7454.

${ }^{6}$ These authors contributed equally to this work.

Article and publication are at www.genesdev.org/cgi/doi/10.1101/ gad.869001. number of signaling events that normally occur after the generation of DNA double strand breaks (DSBs). These findings lead to the widely held view that ATM participates in sensing and initiating signal transduction pathways. These signal transduction pathways regulate the activity of molecules that facilitate cell cycle arrest and DNA repair in response to catastrophic DNA damage induced by ionizing radiation in proliferating cells (Herzog et al. 1998; Cortez et al. 1999; Chong et al. 2000; Gatei et al. 2000; Lim et al. 2000; Petrini 2000; Wang 2000; for reviews, see Rotman and Shiloh 1998; Brown et al. 1999). Abnormalities in checkpoint and repair pathways predictably manifest as the A-T phenotypes of radiosensitivity, germ cell degeneration, mild immunodeficiency, and an extreme sensitivity to developing T-cell lymphomas. However, how the loss of ATM function results in the classic neurodegeneration remains unclear.

Why would a molecule important for initiating cell cycle arrest and DNA DSB repair be required in the nervous system? One possibility is that ATM acts as a component of pathways that sense damage, initiate repair, or eliminate damaged molecules, including proteins, lipids, and DNA. In this context, one could envision a role for ATM after completion of brain development, when the 
majority of cells are postmitotic (and hence may not require cell cycle checkpoint function) but may require ATM for activating macromolecular repair. Thus, in its absence, repair would not occur and consequently, cells would degenerate. Support for this hypothesis comes from recent work demonstrating free-radical induced damage to lipids and proteins in $\mathrm{Atm}^{-1-}$ mice (Barlow et al. 1999). Another possibility is that, during development, ATM functions as a molecule that either directly or indirectly activates cell cycle checkpoints or repair molecules in proliferating neural precursors. In this scenario, the absence of ATM may result in the accumulation of multiple subtle genetic alterations in neuronal precursors as they undergo mitosis before forming mature cells within the brain. Such abnormalities may conceivably manifest later as neurodegeneration.

To clarify the role of ATM in the nervous system in a physiologically relevant context, we used a recently described paradigm to study adult neural stem cells (for review, see Gage 2000). The adult hippocampus generates neural progenitor cells at a significant rate and these cells differentiate into all central nervous system (CNS) cell types (for a recent review, see Gage 2000). The rate of proliferation and survival is greatly increased by environmental stimulation (Kempermann et al. 1998; van Praag et al. 1999). For example, the use of a running wheel to promote voluntary exercise has a dramatic impact on neurogenesis in the dentate gyrus of rodents (van Praag et al. 1999). Such stimulation has been shown to double the number of proliferative cells as well as the number that survive as neurons. We studied this population of cells in wild type and $\mathrm{Atm}^{-/-}$mice in vitro and in vivo, under baseline conditions and in response to running, to understand the requirement for ATM in mitotic and postmitotic neural cells.

\section{Results}

$\mathrm{Atm}^{-/-}$neural progenitor cells in the dentate gyrus show abnormal proliferation and blunted survival in vivo

To test whether ATM is required for normal proliferation of neural precursor cells, we measured cell proliferation in the dentate gyrus in living animals at baseline and in the presence of running wheels to promote voluntary exercise. First, we quantified the amount of running. Surprisingly, in contrast to results reported from prior studies using another strain (van Praag et al. 1999), wild-type $129 \mathrm{SvEv}$ mice show a range of voluntary running. The present study is the first to assess neurogenesis and survival in the adult dentate gyrus using the inbred $129 \mathrm{SvEv}$ mouse strain (for a review on strain nomenclature, see Threadgill et al. 1997); other studies used the C57BL/6 strain, in which all animals ran to a similar degree (van Praag et al. 1999). The average range of running in 129SvEv varied markedly from less than 50 revolutions $(24 \mathrm{~m})$ per night to more than 10,000 revolutions $(4710 \mathrm{~m})$ per night (Fig. 1A,B). This range of voluntary running allowed us to correlate the amount of running to the amount of cell proliferation and survival as measured by BrdU incorporation into dividing neural progenitor cells (see Kempermann et al. 1998; van Praag et al. 1999; Materials and Methods). We found a clear correlation between absolute running and absolute neurogenesis and survival in wild-type mice (Fig. 1). Increasing running correlated with both cell proliferation and survival regardless of the sex studied (Fig. 1A, proliferation, green line: $r^{2}=0.62, P<0.0001$; Fig. $1 \mathrm{~B}$, survival, green line: survival $r^{2}=0.96, P<0.0001$ using Fisher's $R$ to $Z$ transformation). Interestingly, even small amounts of running lead to a substantial increase in neurogenesis and survival.

Next, we compared proliferation and survival of cells in the dentate gyrus between running wild-type and $\mathrm{Atm}^{-/-}$mice (Fig. 1, green = wild type, blue $=\mathrm{Atm}^{-/-}$) . Similar to wild-type mice, $\mathrm{Atm}^{-/-}$mice showed a wide range of running. Therefore, in our comparisons, the amount of running in the two groups was matched. In experiments performed to determine the rate of proliferation, wild-type animals ran an average of 1642 revolutions (range, 47-6266 revolutions; n, 16 animals), which was similar to the amount of running in $\mathrm{Atm}^{-/-}$ animals, which averaged 1891 revolutions (range, 5-7133 revolutions; $n, 18$ animals; $P>0.7$ using a Student's $t$ test). In experiments assessing survival, running in wildtype animals averaged 3009 revolutions (range, 189-9983 revolutions; $\mathrm{n}, 6$ animals) and $\mathrm{Atm}^{-/-}$animals averaged 3242 revolutions (range, 145-8220 revolutions; $n$, 7 animals; $P>0.9$ using a Student's $t$ test).

In studies assessing proliferation of cells in the dentate gyrus (see Materials and Methods), we found that cell proliferation at baseline (i.e., mice housed without running wheels) was higher in $\mathrm{Atm}^{-/-}$mice (Fig. 1A, open blue circles; mean, $3176 ; n=10$ animals) than in wildtype mice (Fig. 1A, open green circles; mean, 2505; $n=7$ animals). However, wild-type animals showed a greater increase in cell proliferation than $\mathrm{Atm}^{-/-}$mice in response to a similar amount of running. The wild-type mice had a mean increase in proliferation of $114 \%$ as compared to an observed mean of $50 \%$ in $\mathrm{Atm}^{-1-}$ mice (Fig. $1 C_{;} P<0.0001$ using a $\chi^{2}$ test). Several of the $\mathrm{Atm}^{-/-}$ mice showed the same rate of proliferation in the absence of running (Fig. 1A, arrowheads pointing to open blue circles) as in the presence of running $>3000$ revolutions per day (Fig. 1A, arrows pointing to filled blue circles). These analyses indicate two defects in the $\mathrm{Atm}^{-/-}$mice: $\mathrm{Atm}^{-1-}$ dentate gyrus brain cells proliferate at a higher rate than normal at baseline and $\mathrm{Atm}^{-1-}$ cells are less able to increase the rate of proliferation to that of wild-type animals in spite of a similar amount of running.

Next, we determined the rate of survival of BrdU-labeled cells in the two groups of animals to test whether the cells that are generated in the $\mathrm{Atm}^{-/-}$dentate gyrus show the same ability to survive as wild type, and whether survival can be enhanced by running. In the absence of running, $25 \%$ of the cells survived in $\mathrm{Atm}^{-/-}$ mice as compared to $30 \%$ in wild type $(P<0.01$ in comparisons of $\mathrm{Atm}^{-/-}$and wild-type mice using a $\chi^{2}$ test). In 
Figure 1. Proliferation and survival of neural progenitor cells in wild-type and $\mathrm{Atm}^{-/-}$dentate gyrus. (A) Correlation between average running in wheel revolutions and total number of proliferating cells in wild-type (green) and $\mathrm{Atm}^{-/}$ (blue) mice. The $\mathrm{x}$-axis indicates the average amount of running measured in revolutions per day; the $y$-axis represents the total number of proliferating cells per granule cell layer corrected for volume. Open colored circles to the left of the dotted vertical line indicate animals with no wheel (green, wild type; blue, $\mathrm{Atm}^{-/-}$). Increased running resulted in less proliferation in $\mathrm{Atm}^{-/-}$ (blue-filled circles and blue line, $r^{2}=0.57$ ) mice than wild-type mice (green-filled circles and green line, $\left.r^{2}=0.62\right)$. Arrowheads indicate $\mathrm{Atm}^{-/-}$animals with cellular proliferation at baseline similar to the amount found in $\mathrm{Atm}^{-/-}$ mice running more than 3000 revolutions per day (arrows). (B) Correlation between average running and total number of surviving cells in wild-type (green) and $\mathrm{Atm}^{-/-}$(blue) mice. The $\mathrm{x}$ axis indicates the average amount of running measured in revolutions per day; the y-axis is the total number of surviving cells per granule cell layer, unfilled circles and dotted vertical line indicate animals with no wheel. Increased running resulted in a substantial and linear increase in
A
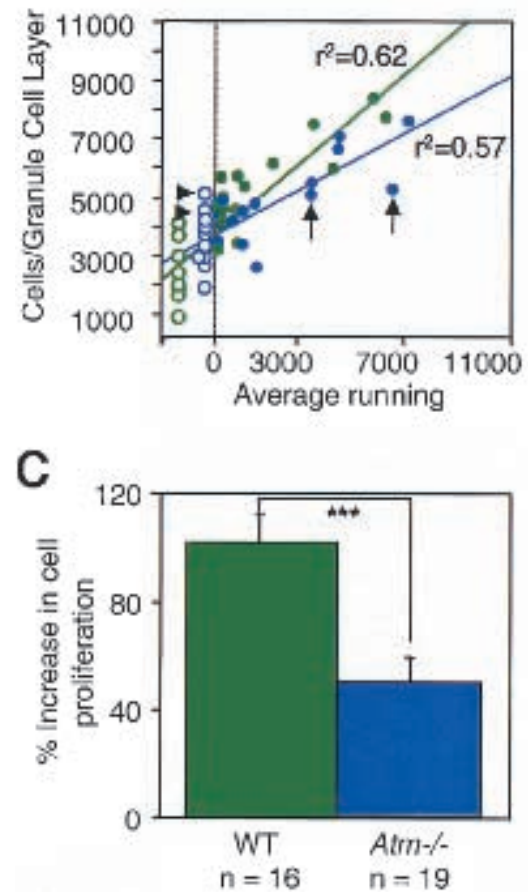

B

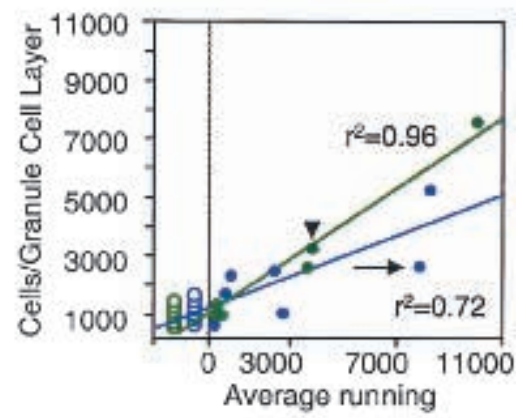

D

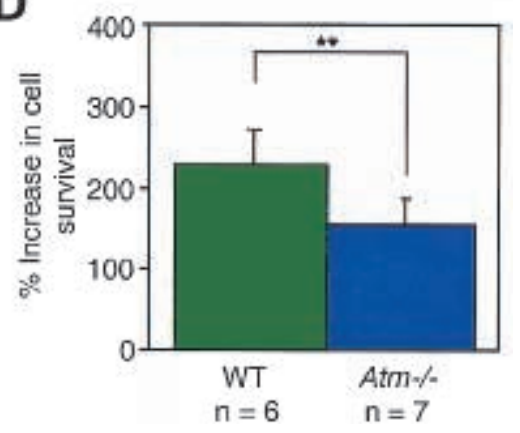
in response to a similar amount of running (blue-filled circles and blue line, $r^{2}=0.72$ ). Arrowhead over green-filled circle indicates a wild-type animal that had the same amount of survival as an $\mathrm{Atm}^{-1-}$ animal that ran more than twice the amount (arrow pointing to blue-filled circle). $(C)$ The percent increase in cell proliferation in wild-type animals (WT, green) is significantly greater than that in $\mathrm{Atm}^{-/-}$mice $\left(\mathrm{Atm}^{-/-}\right.$blue). The $\mathrm{x}$-axis indicates genotype (WT, wild type; $\mathrm{Atm}^{-/-}$, mutants). The y-axis indicates the percent increase in cells that proliferate in response to running. ${ }^{\star \star \star} P<0.0001$ using a $\chi^{2}$ test. $(D)$ The percent increase in cell survival in wild-type animals (WT, green) is significantly greater than that in $\mathrm{Atm}^{-1-}$ mice $\left(\mathrm{Atm}^{-/-}\right.$, blue). The $\mathrm{x}$-axis indicates genotype (WT, wild type; $\mathrm{Atm}^{-/-}$, mutants). The y-axis indicates the percent increase in cells that survive in response to running. ${ }^{\star \star}{ }^{\star} P<0.001$ using a $\chi^{2}$ test.

response to running, both wild-type and $\mathrm{Atm}^{-/-}$mice showed an increase in cell survival (Fig. 1B,D). However, this survival was severely blunted in the $\mathrm{Atm}^{-/-}$mice. Wild-type animals had a $230 \%$ increase and $\mathrm{Atm}^{-1-}$ mice showed a $155 \%$ increase in survival $\left(P<0.001\right.$ using a $\chi^{2}$ test). The increase in cell survival was more prominent and linear in the wild-type mice (Fig. 1B, green line $r^{2}=0.96$ ) than in the $\mathrm{Atm}^{-1-}$ mice (Fig. 1B, blue line $r^{2}=0.72$ ). Therefore, our findings show that, in the absence of ATM, neural progenitor cells that proliferate are less able to survive, and furthermore, providing an enriched environment (running) enhances the survival of $\mathrm{Atm}^{-/-}$progenitor cells, but to a lesser degree than in wild-type cells.

To determine whether BrdU-labeled progenitor cells were able to complete a normal differentiation program in the absence of ATM, we quantified the phenotypic range and number of BrdU-labeled cells that coexpressed markers for neurons, astrocytes, and oligodendrocytes in control and running animals (Fig. 2). The distribution of BrdU-positive cells that expressed neuronal nuclei $(\mathrm{NeuN})$, S100 $\beta$ or were marker negative did not differ significantly between wild-type and $\mathrm{Atm}^{-/-}$mice in the absence of running wheels. However, consistent with previous results in wild-type animals, running resulted in a statistically significant increase in the percentage of surviving cells that were neurons, as evidenced by an increase in the percentage of BrdU-positive cells that colabeled with the neuronal marker NeuN (mean increase, $36 \%$; range, $12-56 \% ; P<0.03$, Student's $t$ test) and by a statistically significant decrease in the percentage of cells that were marker negative (mean decrease, $49 \%$; range, from an increase of $2 \%$ to a decrease of $89 \%$; $P<0.009$, Student's $t$ test) (Fig. 2A,B,D). In contrast, $\mathrm{Atm}^{-/-}$mice failed to show a statistically significant increase in the percentage of cells that became neurons (mean increase, 16\%; range, from a decrease of $25 \%$ to an increase of $36 \% ; P>0.19$, Student's $t$ test) or a decrease in marker negative cells (mean decrease, 22\%; range, from an increase of $27 \%$ to a decrease of $75 \% ; P>0.27$, Student's $t$ test) (Fig. 2A,C,E). The percentage of BrdU cells coexpressing the glial cell marker $\mathrm{S} 100 \beta$ decreased to a similar extent in both wild-type and $\mathrm{Atm}^{-/-}$mice (Fig. 2A).

In conclusion, in the absence of ATM in vivo, neural progenitor cells proliferate at an abnormally high rate, have a decreased rate of survival, and show a blunted response in both proliferation and survival to environmental cues induced by running. In addition, the normal increase in the number of cells that differentiate and 

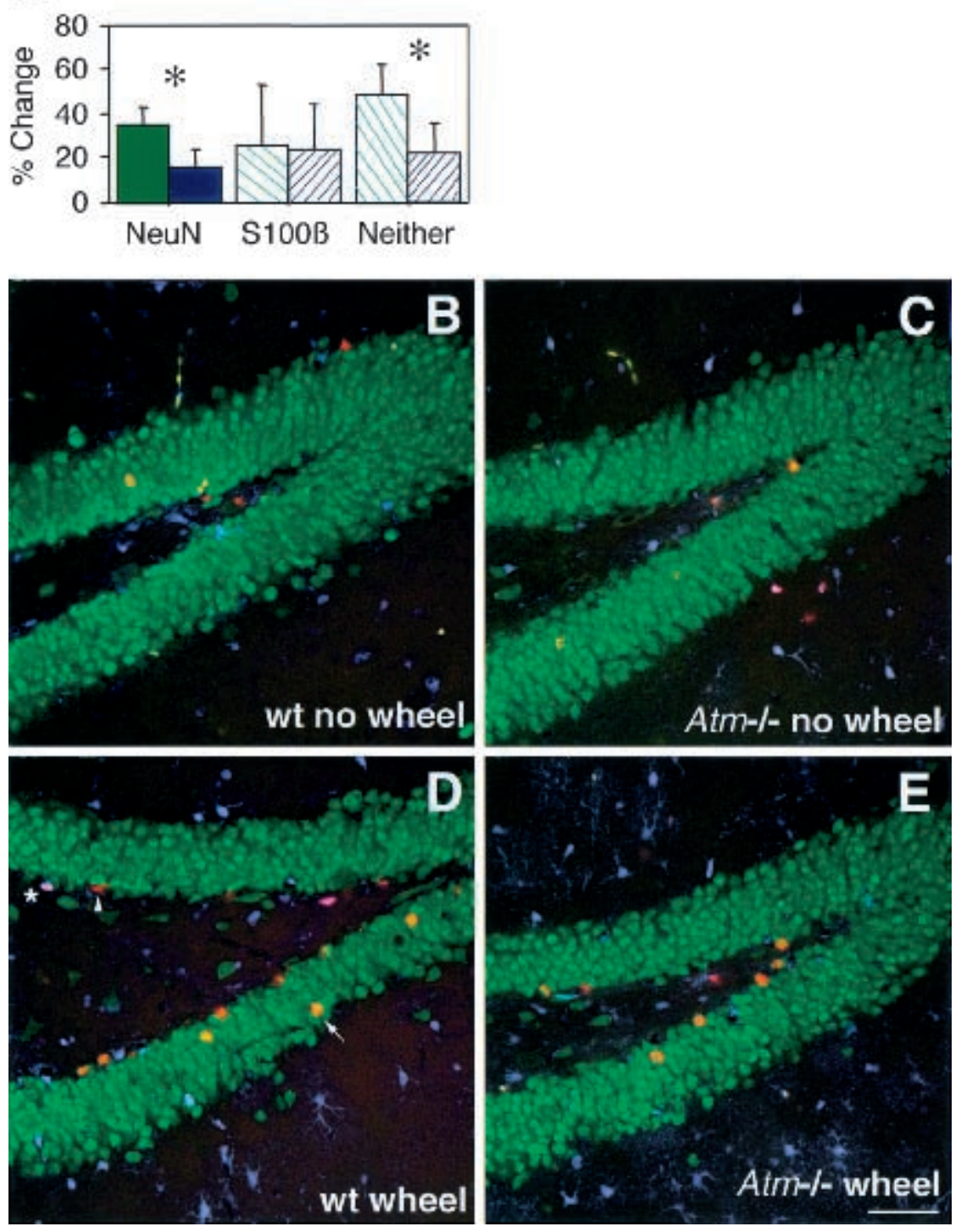

Figure 2. $\mathrm{Atm}^{-/-}$mice do not show a similar increase in the number of neurons that differentiate and survive in response to running as wild-type mice. $(A)$ The percentage increase (solid bars) or decrease (hatched bars) in BrdU-positive cells that stained for the neuronal marker $\mathrm{NeuN}$ or the glial marker $S 100 \beta$ or were marker negative (neither) in wild-type (wt, green) and $A_{\mathrm{tm}^{-/-}}$(blue) animals. $(B-E)$ Representative dentate gyrus sections from $(B, \mathrm{wt}$ no wheel) wild-type and $\left(C, \mathrm{Atm}^{-/-}\right.$no wheel) $\mathrm{Atm}^{-/-}$mice in the absence of running wheels and $(D$, wt wheel) wild-type and (E, $\mathrm{Atm}^{-/-}$wheel) $\mathrm{Atm}^{-1-}$ mice with running wheels. Green staining represents $\mathrm{NeuN}$, blue staining represents $\mathrm{S} 100 \beta$, red staining indicates BrdU (arrowhead). Colabeling of BrdU and NeuN is orange (arrow) and colabeling with $S 100 \beta$ and BrdU is pink $\left({ }^{\star}\right)\left({ }^{\star} P<0.01\right.$ using a $\chi^{2}$ test $)$.

survive as neurons in response to running is markedly decreased in the $\mathrm{Atm}^{-/-}$mouse dentate gyrus.

\section{$\mathrm{Atm}^{-/-}$neural progenitors in vitro fail to differentiate normally}

To further examine the role of ATM in this population of neural progenitor cells, we used an in vitro paradigm. Neural progenitor cells were prepared using a method to isolate mouse neural progenitors from adult hippocampus, and their phenotype was studied in cell culture (see Materials and Methods; Ray and Gage 1999). Comparing $\mathrm{Atm}^{-/-}$and wild-type mice, slightly higher numbers of progenitor cells were isolated from $\mathrm{Atm}^{-/-}$mice (data not shown). At baseline, neither the growth rate of the $\mathrm{Atm}^{-/-}$cells nor their appearance was significantly different from that of wild-type cells (Fig. 3A,B; data not shown). However, upon stimulation to differentiate (two independent preparations, each performed in duplicate using three different strategies as described in Materials and Methods), the $\mathrm{Atm}^{-/-}$cells failed to differentiate to any significant degree into any lineage except astrocytes, regardless of the factor or condition used (Fig. 3D,G,K), whereas wild-type cells were able to differentiate along all lineages (Fig. 3C,E,F,H-J,L). As shown, only wild-type cells showed morphology (Fig. 3C wild-type and 3D $\mathrm{Atm}^{-/-}$mice) and marker expression consistent with complete differentiation into oligodendrocytes (Fig. 3E,F, green staining), and fully differentiated neurons as evidenced by morphology and Map2ab staining (Fig. 3H-J, green staining). No similar cells were detected in $\mathrm{Atm}^{-/-}$ preparations (Fig. 3G; data not shown). However, morphologically normal astrocytes were found in both genotypes (Fig. 3E, wild-type and 3G in $\mathrm{Atm}^{-/-}$mice, glial fibrillary acidic protein [GFAP] in red). Interestingly, although the $\mathrm{Atm}^{-/-}$cells were unable to complete a dif- 
Figure 3. Lack of normal differentiation in $\mathrm{Atm}^{-/-}$neural progenitor preparations. Baseline morphology and differentiation of wild-type and $\mathrm{Atm}^{-/-}$neural progenitor cells. Undifferentiated cells have a similar morphology in both wild-type $(A$, wt u) and $\mathrm{Atm}^{-/-}\left(B, \mathrm{Atm}^{-/-} \mathrm{u}\right)$ cells. With stimulation to differentiate, wild-type $(C$, wt d) cells flatten out and extend processes (arrows), whereas $\mathrm{Atm}^{-/-}$cells $\left(D, \mathrm{Atm}^{-/-}\right.$ d) flatten out and cease dividing but do not extend processes. Immunohistochemistry using RIP to detect oligodendrocytes (green) and glial fibrilary acidic protein (GFAP) to detect astrocytes (red) in differentiated wild-type $(E, F, \mathrm{wt})$ and $\mathrm{Atm}^{-/-}(G$, $A \mathrm{tm}^{-/-}$) progenitor preparations. Note that only wild-type $(E, F)$ cells show RIP staining, whereas astrocytes were detected in both genotypes (wild type, E,F; Atm-/-, $G)$, Map2ab staining of differentiated neurons in wild-type $(H-J, w t)$ mice preparations. No normal-appearing neurons were found in $\mathrm{Atm}^{-/-}$preparations, although rare cells that stained for Map2ab but did not extend normal processes were detected $\left(\mathrm{K}, \mathrm{Atm}^{-/-}\right.$and blue indicates DAPI staining). TUJ1-positive cells were readily identified in wild-type $(L, \mathrm{wt})$ but not in Atm $^{-/-}$cultures. (M) Bar graph depicting the number of cells per high power field (y-axis, cells/hpf) that stained for Map2ab, RIP, or GFAP in wild-type (green) and $\mathrm{Atm}^{-/-}$(blue) mice. ${ }^{\star} P<0.03$ using a Student's $t$ test.
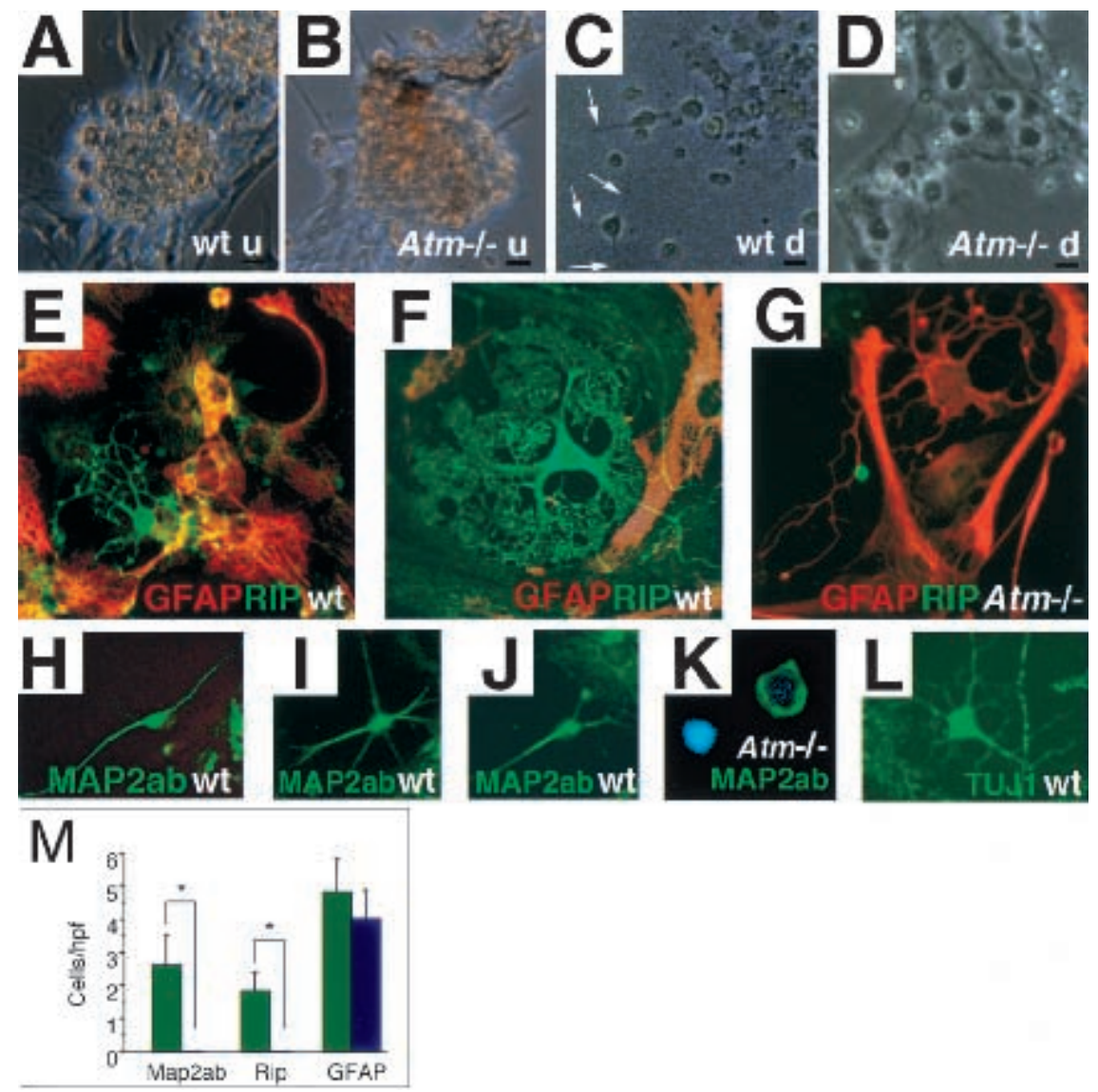

ferentiation program for oligodendrocytes or neurons, they did exit the cell cycle, cease dividing, and attempt to differentiate as evidenced by lack of proliferation in culture (Fig. 3D). This phenotype was not altered by extending the time of differentiation to $14 \mathrm{~d}$ (data not shown), suggesting that the effect on differentiation was an inability to complete the process rather than a delay in the ability to differentiate. The in vitro findings suggest that the minimal environmental stimulation that promotes wild-type differentiation of neurons in cell culture is insufficient for the $\mathrm{Atm}^{-/-}$cells.

\section{ATM is required to maintain genomic stability of proliferating neural progenitor cells}

Recent evidence suggests that some, but not all, proteins involved in repair of DSBs generated during $\mathrm{V}(\mathrm{D}) \mathrm{J}$ recombination in cells of the immune system are also important during neuronal development (Gao et al. 1998; Gu et al. 2000). The lymphomas that develop in $\mathrm{Atm}^{-/-}$mice contain chromosomal rearrangements that reflect defective recombination during T-cell development (Liyanage et al. 2000). To clarify whether ATM has a similar role in maintaining genomic stability during neurogenesis, spectral karyotyping (SKY) was performed on two independent early passage neural progenitor preparations.
This technique allows the visualization of each mouse chromosome in a different color (Liyanage et al. 1996). The majority of neural progenitors from $\mathrm{Atm}^{-/-}$mice have chromosomal aberrations, whereas no aberrations were found in wild-type progenitors (Table 1; Fig. 4; data not shown). Because T cells from $\mathrm{Atm}^{-/-}$mice show consistent defects in cell differentiation and an inability to appropriately recombine the T-cell receptor- $\alpha$ (TCR $\alpha$ ) locus, we determined whether there were any consistent chromosomal abnormalities in the neural progenitor cells. Although there were a range of aberrations, including translocations and chromatid breaks, chromosomes 18 and 4 were more frequently involved in aberrations than the other chromosomes (see Table 1). Interestingly, chromosome 18 harbors one of the mouse protocadherin loci, referred to as the cadherin-related neuronal receptor (CNR) gene locus (Sugino et al. 2000). In both human and mouse, this locus has a unique organization reminiscent of the organization of loci that undergo recombination during $\mathrm{V}(\mathrm{D}) \mathrm{J}$ rearrangement $(\mathrm{Wu}$ and Maniatis 1999, 2000). However, using fluorescent in situ hybridization of gene-specific bacterial artificial chromosome (BAC) probes combined with a whole chromosome paint to study the mouse locus, no abnormalities were found at this cadherin locus in either wild-type or $\mathrm{Atm}^{-/-}$neural progenitor preparations in 20 of 20 metaphases analyzed (Fig. 4D-F; data not shown). 
Table 1. Chromosomal aberrations in $\mathrm{Atm}^{-/-}$neural progenitor cells

\begin{tabular}{|c|c|}
\hline $\mathrm{Atm}^{-/-}$prep $1^{\mathrm{a}}$ & Aberrations \\
\hline$\# 1$ & 4n, Ace(4), Ace (11), Ace(15) \\
\hline$\# 2$ & Ace(14) \\
\hline \#3 & chromatid break (7) \\
\hline$\# 4$ & $\mathrm{Rb}(13 . \mathrm{X})$ \\
\hline \multicolumn{2}{|l|}{$\mathrm{Atm}^{-/-}$prep $2^{\mathrm{b}}$} \\
\hline$\# 1$ & $\mathrm{~T}(1 ; 5)$ \\
\hline$\# 2$ & $\mathrm{~T}(19 ; 9)$ \\
\hline \#3 & $\mathrm{T}(4 ; 18), \mathrm{T}(18 ; 4)$ \\
\hline \#4 & $\mathrm{T}(4 ; 18)$ \\
\hline \#5 & $\mathrm{T}(1 ; 15) ; \mathrm{T}(15 ; 1)$, chromatid break $(3)$ \\
\hline \#6 & $\mathrm{T}(18 ; 6)$ \\
\hline$\# 7$ & chromatid break (4) \\
\hline$\# 8$ & chromatid break (11) \\
\hline \#9 & $\operatorname{Dp}(8)$ \\
\hline
\end{tabular}

$\mathrm{n}$, Ploidy; Ace, acentric fragment; $\mathrm{Dp}$, duplication; Rb, Robertsonian translocation; $\mathrm{T}$, translocation (the chromosome donating the centromere is listed first).

${ }^{\text {a}}$ Four of ten metaphases abnormal.

${ }^{\mathrm{b}}$ Nine of eleven metaphases abnormal.

The findings outlined suggest that although $\mathrm{Atm}^{-/-}$ cells retain proliferative ability, multiple subtle genetic mutations may impair their ability to execute a full differentiation program in vitro and also impair their survival in vivo. Furthermore, the finding of genomic instability is reminiscent of that found in lymphoid populations in patients with $\mathrm{A}-\mathrm{T}$ and from $\mathrm{Atm}^{-/-}$mice, suggesting that neural progenitors require DNA repair of DSBs at a rate similar to developing T cells (Barlow et al. 1996; Liyanage et al. 2000).

\section{ATM is abundant in proliferating neural stem cells but is down-regulated with differentiation}

To study the localization and abundance of ATM in neural progenitor cells we developed an anti-serum to the mouse homolog of ATM, designated pAb 855m (see Materials and Methods). Immunofluorescence assays displayed positive immunostaining in the nucleus and cytoplasm of wild-type neural progenitor cells (Fig. 5A, $\mathrm{A}^{\prime}$ ), whereas neural progenitors from $\mathrm{Atm}^{-/-}$mice showed markedly reduced immunoreactivity (Fig. 5B, $\mathrm{B}^{\prime}$ ), indicating the specificity of the observed staining with $\mathrm{pAb}$ $855 \mathrm{~m}$. Furthermore, after differentiation (see Materials and Methods), only background levels of immunostaining were observed in both wild-type and $\mathrm{Atm}^{-/-}$cells (Fig. $\left.5 \mathrm{C}, \mathrm{C}^{\prime}, \mathrm{D}^{\prime} \mathrm{D}^{\prime}\right)$. These observations suggest that ATM abundance in neural progenitor cells dramatically decreases during in vitro differentiation.

To independently confirm our immunohistochemical observations, we conducted immunoblot analysis on SDS extracts of neural progenitor cells (Fig. 6A, top). Immunoblot analysis of equivalent protein loads from cultures of undifferentiated or differentiated wild-type cells displayed a strong ATM signal in extracts of proliferat- ing, undifferentiated wild-type cells, whereas a markedly reduced signal was present in extracts from differentiated wild-type neural progenitors. Quantitative analysis of several independent immunoblotting experiments indicated a 5.5 -fold reduction $( \pm 0.8$-fold, $n=4)$ in ATM after differentiation. As expected and consistent with previous observations (Barlow et al. 1997), we detected no ATM in cells derived from $\mathrm{Atm}^{-1-}$ mice (Figs. 5,6A). Parallel immunoblots probed with an $\alpha$-tubulin antibody confirmed equivalency of protein loading (Fig. 6A, bottom).

Then, we subjected undifferentiated wild-type neural progenitor cells to a subcellular fractionation protocol. Nuclear and cytoplasmic fractions were obtained from these cells and equal percentages of these fractions were subjected to ATM immunoblot analysis (Fig. 6B, top). Consistent with our immunofluorescence microscopy data, we observed that ATM was present in both the nuclear and cytoplasmic fractions of these cells. Quantitative analysis of such blots indicates that $~ 80 \%$ of the ATM is present in the nuclear fraction, consistent with findings observed on a variety of non-neuronal cell types (Lakin et al. 1996; Brown et al. 1997; Watters et al. 1997). Parallel immunoblots probed for $\alpha$-tubulin (a cytoplasmic protein) and Ku-70 (a nuclear protein) confirmed the integrity of the fractions and that cell lysis was complete (Fig. 6B, bottom). It should be noted that we could detect ATM in whole cell extracts but were unable to detect ATM in either nuclear or cytoplasmic fractions obtained from postmitotic, differentiated wild-type neural progenitors (data not shown), likely stemming from quantitative loss of the protein during fractionation. Nevertheless, these findings clearly indicate that neural progenitor cells possess both substantial nuclear and lesser but detectable cytoplasmic pools of ATM and that the cellular abundance of this protein is markedly decreased once cells have differentiated.

\section{Discussion}

The findings outlined demonstrate that ATM is essential for the normal development and differentiation of adult neural progenitor cells. Previous studies have demonstrated that ATM, by way of p53, is required to induce apoptosis after massive DNA damage in the developing nervous system (Herzog et al. 1998; Chong et al. 2000; Lee et al. 2000). In these studies, loss of ATM rescues the developing nervous system from cell death (see Fig. 7, left). In contrast, our study suggests that the physiological roles of ATM (i.e., in the absence of ionizing radiation [IR]) are multiple and that loss of ATM results in selective abnormalities in neural progenitors both in vivo and in vitro that differentiate along a nonastrocytic lineage (see Fig.7, right). Therefore, our work extends that of prior studies, suggesting a role for ATM during neural progenitor proliferation and demonstrates that loss of ATM ultimately results in neuronal cell loss.

We have shown that $\mathrm{Atm}^{-/-}$progenitor cells show abnormally high proliferation at baseline and genomic instability indicative of a role for ATM in the maintenance 


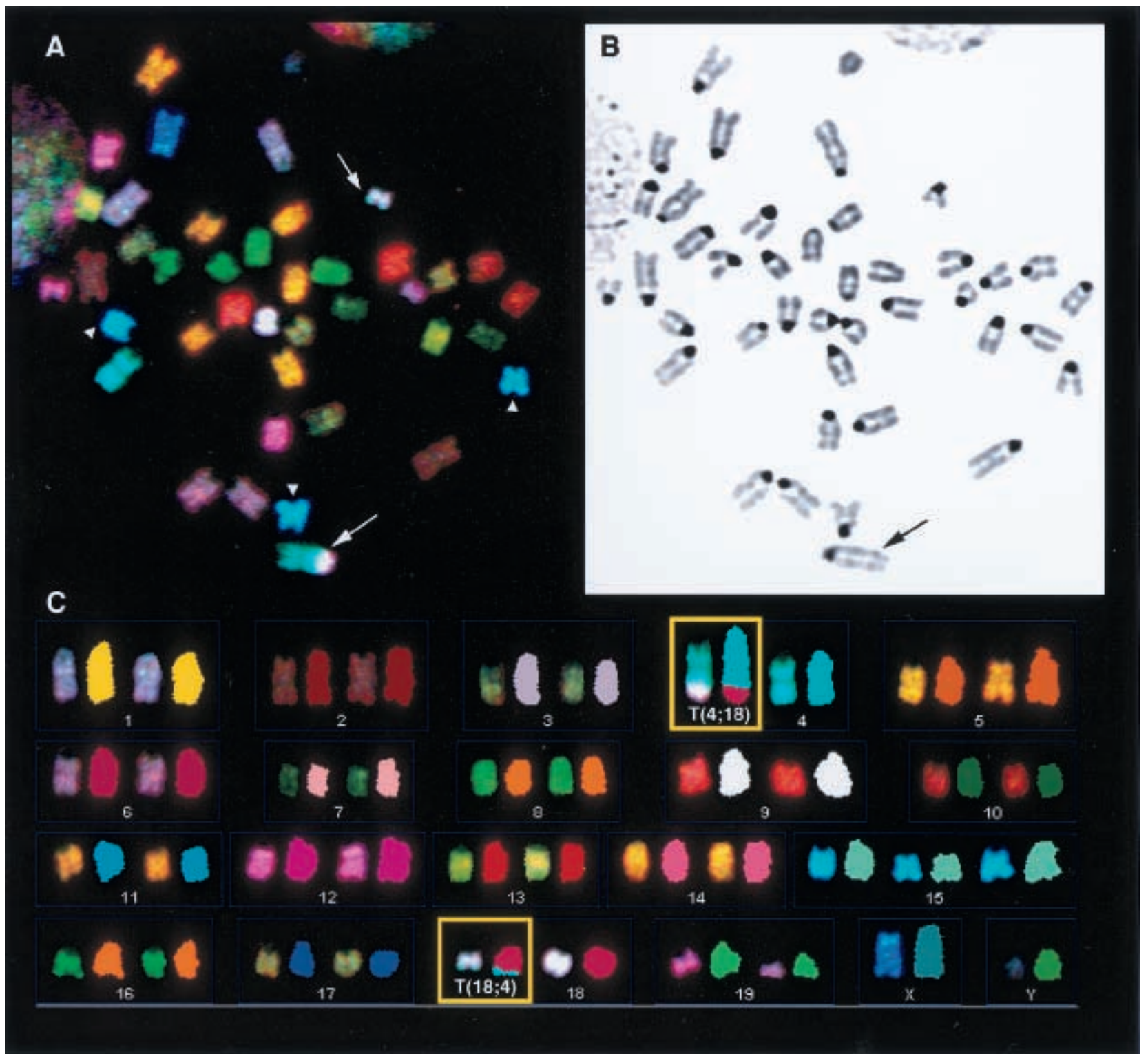

Figure 4. Genomic instability in $\mathrm{Atm}^{-/-}$neural progenitor cells. Representative spectral karyotype demonstrating nonclonal chromosomal rearrangements in the absence of ATM in proliferating neural progenitor cells. $(A-C)$ Spectral karyotyping analysis of a representative metaphase, $41 \mathrm{XY}, \mathrm{T}(4 ; 18)$, and $\mathrm{T}(18 ; 4),+15$, shown in hybridization display colors $(A)$ next to the inverted DAPI-banded image $(B)$. Arrows indicate the reciprocal translocation breakpoints, and arrowheads indicate the three copies of chromosome 15 . The fully classified metaphase is shown in $C$. Each chromosome is shown in display colors next to the spectra-based classification pseudocolors. ( $D-F)$ FISH using a 5' specific probe to the CNR locus. The CNR 5' probe is displayed in red in $D$ and the 3'-specific probe is shown in yellow in $E$. An overlay including the paint of chromosome 18 (green) in $F$ demonstrates no rearrangement within this locus.

of genomic integrity during cell growth in vivo. We also observed that cells of the dentate gyrus of $\mathrm{Atm}^{-/-}$mice show a significant decrease in survival of proliferating neurons compared to wild-type mice, indicating a role for ATM in neural progenitor survival or differentiation. In addition, we found that $\mathrm{Atm}^{-1-}$ neural progenitor cells are less able to respond to environmental cues that promote neuronal differentiation of Atm-proficient cells in vivo. This abnormality is magnified in vitro, resulting in a complete failure of $\mathrm{Atm}^{-/-}$cells to differentiate into neurons or oligodendrocytes. Such findings strongly sug- gest that the neuronal dysfunction displayed by A-T patients is the result of a combination of defects that arise during the proliferative phase of the neural progenitor cell life cycle in combination with subsequent defects, which results in neuronal cell loss. Consistent with this view is that ATM is of highest abundance before differentiation, indicating a role for this protein that may not be used in postmitotic neurons. Dysfunctions arising from a lack of ATM during development could potentially manifest themselves in postmitotic neurons and other nervous system cell types as a decrease in the abil- 


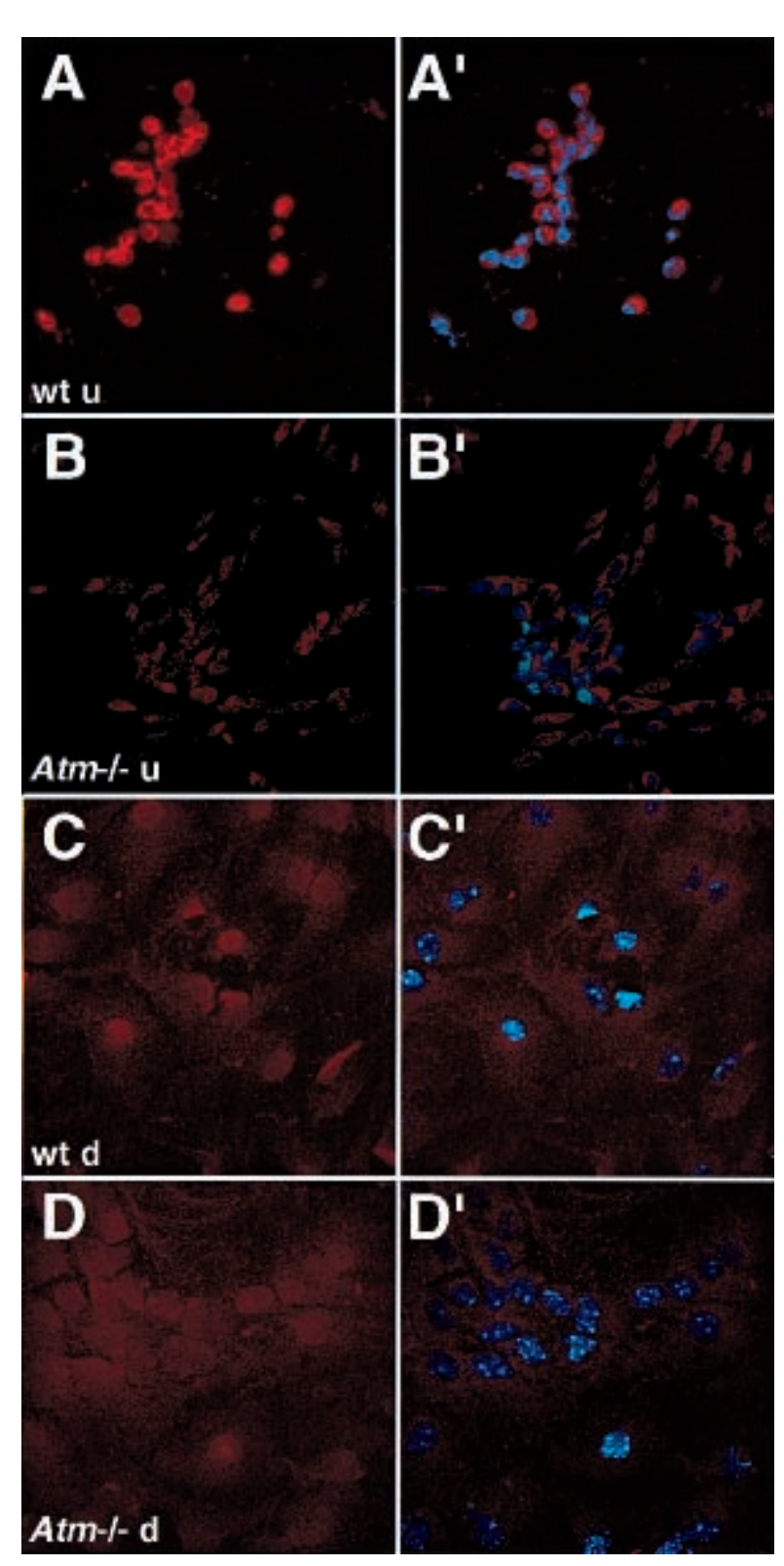

Figure 5. ATM is abundant in dividing neural progenitors. Neural progenitor cells were isolated from the brains of wildtype (wt) or $\mathrm{Atm}^{-/-}$mice as outlined in Materials and Methods. Cultures of these cells were fixed and stained with the ATM antisera pAb $855 \mathrm{~m}$ and counterstained with DAPI to reveal the DNA. Images $A-D$ are the pAb $855 \mathrm{~m}$ staining alone, whereas images $A^{\prime}-D^{\prime}$ are merged images showing both the pAb $855 \mathrm{~m}$ and DAPI staining. $\left(A, A^{\prime}\right)$ Undifferentiated wild-type (wt u) neural progenitor cells. $\left(B, B^{\prime}\right)$ Undifferentiated $\mathrm{Atm}^{-1-}\left(\mathrm{Atm}^{-1-} \mathrm{u}\right)$ neural progenitor cells. $\left(C, C^{\prime}\right)$ Neural progenitors from wildtype brain after differentiation (wt d) by addition of retinoic acid and serum. $\left(D, D^{\prime}\right)$ Neural progenitors from $\mathrm{Atm}^{-1-}$ brain after treatment with retinoic acid and serum $\left(\mathrm{Atm}^{-/-} \mathrm{d}\right)$. Note the strong staining present in the wild-type undifferentiated neural progenitors but that this staining is absent from both the differentiated wild-type cells and the Atm-deficient cells. Furthermore, note that the observed pAb $855 \mathrm{~m}$ staining (red) in $A^{\prime}$ extends beyond the DAPI staining (blue) nucleus, suggesting that a pool of ATM exists within the cytoplasm of these cells.
A

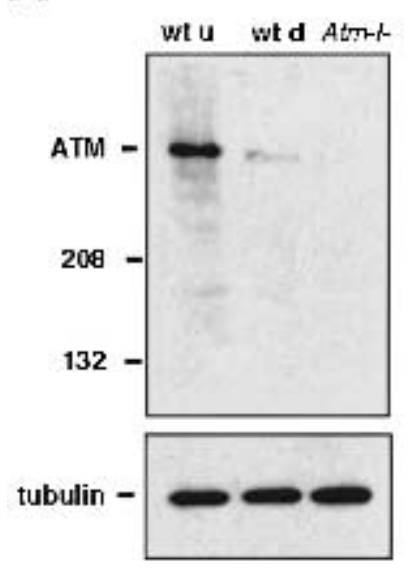

B

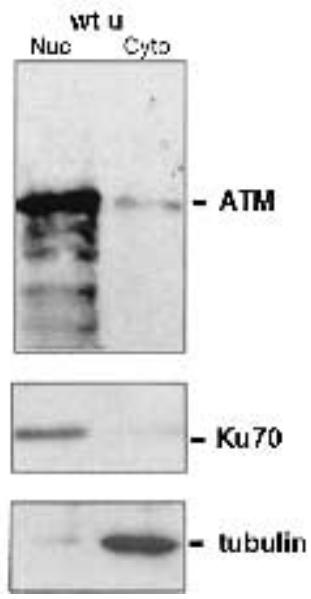

Figure 6. ATM is present in both the nuclear and cytoplasmic compartments of neural progenitors and is quantitatively lost during differentiation in vitro. (A) SDS extracts were formed from cultures of wild-type undifferentiated (wt u), wild-type differentiated (wt d), and $\mathrm{Atm}^{-/-}$neural progenitors $\left(\mathrm{Atm}^{-/-}\right)$and $100 \mu \mathrm{g}$ of total protein from each extract was subjected to immunoblot analysis. Note the robust ATM immunoreactivity present in the wild-type undifferentiated extract, the slight band present in the extract from wild-type differentiated cells, and the lack of immunoreactivity in $\mathrm{Atm}^{-1-}$ cells. $(B)$ Undifferentiated wild-type neural progenitors were subjected to subcellular fractionation and equal percentages $(3 \%)$ of the resultant nuclear and cytoplasmic fractions were subjected to immunoblot analysis. Note the presence of ATM in both the nuclear and cytoplasmic fractions.

ity of the cells to survive, differentiate, or function normally within the developed CNS.

Future studies to determine how ATM-dependent defects that arise before and during development result in age-dependent neuronal cell loss are needed to more fully appreciate the causes of the progressive neuronal dysfunction displayed by A-T patients. For example, it is plausible that this cell population, which is compromised during development, has heightened sensitivity to cellular damage caused by the generation of reactive oxygen species (ROS) because of unrepaired genome damage or normal aging and metabolism. If such a scenario were occurring within the $\mathrm{Atm}^{-/-} \mathrm{CNS}$, then cellular damage that occurs postmitotically could reach a certain threshold that propels cells into an apoptotic pathway resulting in neuronal cell loss. As we have shown in this study, these cells exist in a compromised state during their development; thus, cellular insults that may be readily tolerated by normal cells may have a more profound effect on $\mathrm{Atm}^{-/-}$cells, leading to their degeneration.

Because we have shown that ATM is also present in the cytoplasm of proliferating adult neural progenitors and Purkinje cells in situ (Barlow et al. 2000), we should also consider that this protein is likely to have an as yet undefined cytoplasmic role in cells of the nervous system. Recently, it was shown that mutations in the Drosophila mus304 gene, which encodes a cytoplasmic pro- 
Figure 7. Comparison of ATM function in catastrophic and normal physiological contexts. Shown is a comparison of the presumptive role of ATM in the early events (proliferation) and late events (cell fate determination and survival) of neurogenesis. In response to catastrophic DNA damage (either ionizing radiation or absence of DNA ligase IV/XRCC4) (left), neural stem cells (NS) proliferate but neural progenitors (NP) and lineage-restricted precursors $(\mathrm{RP})$ undergo programmed cell death. The cell death induced by massive DNA damage is dependent on ATM signaling to p53 to activate apoptosis. The absence of ATM or p53 rescues the cell death phenotype and the cells differentiate along all lineages and survive. Therefore, in the setting of catastrophic DNA damage, loss of ATM, results in enhanced survival of neural progenitors. In contrast, under normal physiological conditions (right), ATM is required to maintain appropriate cell cycle checkpoints at baseline and in response to growth cues and also contributes to maintaining genomic stability. An additional role for ATM in cell fate determination and survival is then apparent as these cells mature. In the absence of ATM, NP cells are able to proliferate but have a decreased ability to differentiate along a nonastrocytic lineage. In this setting, ATM is required for both the normal differentiation and survival of neurons and oligodendroctyes. Therefore, under physiologic conditions, the lack of ATM results in the decreased production and the diminished survival of neurons and oligodendroctyes.

tein, result in a phenotype in the developing neuroblast similar to that found in mei-41 mutants (the presumptive Drosophila ATM homolog; Brodsky et al. 2000). Thus, like mus304, ATM may participate in cytoplasmic signaling cascades that promote neuronal survival and differentiation. The decrease in survival of the proliferating neural cells and the lack of differentiation in cell culture may be consistent with a defect in signaling pathways activated by environmental cues and may indicate that such a function is required for continued neuronal survival. Clearly, a greater understanding of the functions of ATM in brain cells, both before and after differentiation, is needed to resolve these issues.

Mice with a mutation in the delta-2 glutamate receptor gene (lurcher mutants) show enhanced survival and improved behavioral function in an enriched environment (Caston et al. 1999). The $\mathrm{Atm}^{-/-}$mice also showed enhanced (albeit not to wild-type levels) sur-vival of neurons in response to running. Such findings indicate that enhancement of neuronal stimulation improves neuronal viability in the absence of ATM, suggesting that providing an appropriate stimulatory environment to patients with A-T may slow the course of the disease.

\section{DNA damage repair and response mechanisms are required for proper neuronal development}

A-T is caused by loss or severe diminishment of ATM function. Another genetic disorder that closely re- sembles A-T is caused by hypomorphic mutations in the DNA repair protein MRE-11 (Stewart et al. 1999). MRE11 participates in nonhomologous-end-joining (NHEJ), the repair pathway important for resolving DNA breaks introduced during recombination in the immune system and by ionizing radiation (Paull and Gellert 1998, 1999; for review, see Haber 1998). Furthermore, MRE-11, as well as ATM, serves additional functions such as telomeric maintenance and cell cycle checkpoint activation in response to chromosome damage (for reviews, see Haber 1998; Petrini 2000).

Recent evidence demonstrates that molecules involved in facilitating NHEJ after DNA recombination within the immune system also play important roles in brain development. For example, mice with mutations in DNA ligase IV and XRCC4 have abnormal brain development associated with increased apoptosis in both the developing nervous and immune systems (Frank et al. 1998; Gao et al. 1998). Removal of p53 or ATM from XRCC-4/DNA ligase IV-deficient mice rescues neural development but not the defects in the immune system (Gao et al. 2000; Lee et al. 2000), suggesting that the observed apoptosis in response to catastrophic DNA damage within the developing brain are both ATM and p53-dependent in nature.

Similarly, the protein kinase complex DNA-PK, which is a critical component of the NHEJ machinery in the immune system, may also have an important role in neuronal development. DNA-PK is a heterotrimeric 
complex consisting of DNA-PKcs (an ATM-related kinase) and a regulatory complex consisting of the $\mathrm{Ku} 70$ / Ku80 heterodimer. Although loss of DNA-PKcs has profound effects on immune system development, no similar effect was noted within the nervous system. However, mice deficient in either Ku70 or Ku80 showed an increase in apoptotic neurons during development (Gao 1998; Gu 2000), suggesting an important role for the Ku70/Ku80 complex during development that is independent from DNA-PK function. Ku70/Ku80 has been proposed to play an important role in DNA repair (for review, see Haber 1999), facilitated in part by its ability to bind to free DNA ends. Furthermore, the ligase IV-, XRCC4-, and Ku-deficient mice show decreased neuronal progenitor survival within the developing embryonic CNS. Taken together, these findings suggest that neuronal progenitors are highly prone to incurring genome damage and that an inability to appropriately respond to such damage results in a substantive loss in viability during brain development. Although we are unsure of the mechanisms that underlie this proposed increase in the rate of DNA damage, the possibility that the genome of neurons undergoes somatic recombination has recently received attention (Wu and Maniatis 1999, 2000).

Importantly, the fact that the $\mathrm{Atm}^{-/-}$mouse model shows essentially normal brain development (Barlow et al. 1996; Xu et al. 1996) suggests that the abnormalities observed in neural progenitors do not a priori give rise to abnormally developed neurons destined to undergo degeneration. We have discovered that cells within the adult brain of $\mathrm{Atm}^{-/-}$mice show compromised viability and an intrinsic inability to appropriately respond to differentiation and survival cues both in vivo and in vitro, pointing to a complex role for ATM during development and a continued role in cell survival. Whereas the case for the requirement for proteins involved in the maintenance of genome integrity in normal brain development is strong, our data also demonstrate the neuronal degeneration that occurs in A-T patients is due to additional defects in responding to survival and cell fate cues.

\section{Materials and methods}

\section{Running wheel experiments}

All animal procedures were performed according to protocols approved by The Salk Institute for Biological Studies animal care and use committees. Generation of animals and genotyping were done as described (Barlow et al. 1996) except that all animals used in this study were maintained in an inbred 129SvEv background. $\mathrm{Atm}^{-/-}$and wild-type age- and sex-matched controls were divided into two groups maintained in standard sterile caging either without (baseline/control) or with a running wheel (enriched environment). Running wheels were $15 \mathrm{~cm}$ in diameter. Revolutions were counted electronically and recorded daily. All animals received their first BrdU injection between the ages of $28 \mathrm{~d}$ and $31 \mathrm{~d}$. Animals were sacrificed between 41 and $44 \mathrm{~d}$ of age for short time point experiments measuring proliferation, and between 68 and $71 \mathrm{~d}$ of age for long time point experiments measuring survival. BrdU (Sigma) was dissolved in $0.9 \% \mathrm{NaCl}$ at a concentration of $10 \mathrm{mg} / \mathrm{mL}$ and sterile filtered using a $0.2-\mu \mathrm{m}$ filter. Mice were injected intraperitoneally once daily for 12 consecutive days at a dose of $50 \mathrm{mg} / \mathrm{g}$ of body weight.

\section{Immunohistochemistry}

Mice were anesthetized and perfused with cold $4 \%$ parafomaldehyde transcardially. Brains were dissected and submerged in $30 \%$ sucrose for $2 \mathrm{~d}$ before microtome sectioning $(40 \mu \mathrm{m})$. Stereology and absolute counts were performed using a mouse antiBrdU antibody and DAB secondary reagent. Immunofluorescence using triple labeling to phenotype cells was performed with rat anti-BrdU, NeuN (differentiated neuronal marker), and S100 $\beta$ (astrocytic marker) on free-floating $40-\mu \mathrm{m}$ sections as described (Kuhn et al. 1997). The antibodies used were mouse anti-BrdU (Boehringer Mannheim) 1:400; rat anti-BrdU ascites (Accurate Harlan Sera-Lab, Loughborough, England; for triple labeling), 1:100; rabbit anti-S100 $\beta$ (Swant, Bellinoza, Switzerland) 1:2500; and mouse anti-NeuN (kindly provided by R.J. Mullen, University of Utah, Salt Lake City) 1:20. The fluorescent secondary antibodies used were anti-mouse FITC, anti-rat Texas Red, and anti-rabbit Cy5 (Jackson ImmunoResearch, West Grove, PA), $6 \mu \mathrm{g} / \mathrm{mL}$.

\section{Stereology}

BrdU-positive cells were counted in a one-in-six series of sections $(240 \mu \mathrm{m}$ apart) through a $40 \times$ objective (Leitz) throughout the rostrocaudal extent of the granule cell layer. A one-in-six series of adjacent sections stained with Hoechst 33342 (Molecular Probes, Eugene, OR) was used to measure granule cell layer volume. The granule cell area was traced using a semiautomatic stereology system (StereoInvestigator, MicroBrightfield) and a $10 \times$ objective. Total numbers of BrdU-positive cells were calculated as described previously (van Praag et al. 1999), which includes a correction for volume. Statistical analysis was performed using Statview.

\section{Analysis of phenotype}

A one-in-six series of sections from animals surviving $4 \mathrm{wk}$ after the last injection of BrdU was triple-labeled as described above and analyzed by confocal microscopy, and 25 cells per animal were counted (Zeiss, Bio-Rad, Richmond, CA). Statistical analysis was performed using Statview.

\section{Cell culture}

Animals were sacrificed at postnatal day 28-44. Brains were removed and the olfactory bulb, cerebellum, and brainstem were discarded. The cells were prepared as described (Ray and Gage 1999). Briefly, the brain was transferred to a $10-\mathrm{cm}$ Petri dish, cut into small pieces $\left(1-2 \mathrm{~mm}^{3}\right)$, washed with HEPES buffered salt solution (HBSS), resuspended in $5 \mathrm{~mL}$ of papain-protease-DNAse (PPD) solution, and incubated for $15 \mathrm{~min}$ in a $37^{\circ} \mathrm{C}$ water bath with occasional gentle shaking. Trituration and incubation were continued until the cell suspension was free of visible tissue pieces. The cell suspension was centrifuged at $1000 \mathrm{~g}$ for $3 \mathrm{~min}$; supernatant was discarded and the pellet was resuspended and washed in DMEM:F12 containing 10\% fetal bovine serum (FBS) $(10 \mathrm{~mL} / \mathrm{g}$ of starting tissue weight). The final pellet was resuspended in N2 medium containing 10\% FBS. Further purification was performed using Percoll density gradient centrifugation. Cells were plated $\left(25-1000\right.$ cells $\left./ \mathrm{cm}^{2}\right)$ in uncoated six-well plates in serum-free N2 medium containing epidermal growth factor (EGF) and fibroblast growth factor-2 (FGF- 
Allen et al.

2) at concentrations of $20 \mathrm{ng} / \mathrm{mL}$ and heparin $(5 \mu \mathrm{g} / \mathrm{mL})$. Cells were maintained and passaged as neurospheres and monolayers.

\section{Differentiation and immunophenotyping of neural progenitors}

Cells were plated onto polyornithine/laminin-coated chamber slides in the presence of $0.5 \%$ FBS and either $1 \mu \mathrm{m}$ of retinoic acid, $20 \mathrm{ng} / \mathrm{mL}$ brain-derived neurotrophic factor or $5 \mu \mathrm{m}$ of forskolin, and allowed to differentiate for 7-14 d. Cells were fixed using 4\% paraformaldehyde and stained according to published protocols (Palmer et al. 1997). Data were analyzed and images captured using a confocal microscope (Bio-Rad).

\section{Spectral karyotyping}

SKY was performed on two independent cell preparations at passage 3 according to standard protocols (Liyanage et al. 1996).

\section{Fluorescent in situ hybridization}

PCR was used to identify two separate BACs containing either the variable (CNR2) or constant region (CNRcon) exons of the mouse CNR locus. PCR screening was performed using Genome Systems BAC Mouse ES (release I, II) and primers specific for the variable exon 2 (CNR2) and for constant exon 3 of the CNR locus as follows: CNR2 primers: CNR2F1, 5' -AATCAAA CAGCGATGGCAAC-3'; CNR2B1, 5'-AAGAGTCTTGGGCG GCACCAGTCTATT-3'; CNRcon primers: CNRconF1, 5'-CG GCAAAAAGGAGGAGACCAAG-3'; CNR conB1, 5' ATAGG AGAAAGGAGCGGGGAGTTG-3'. PCR was performed using PE GeneAmp PCR 9700 as follows: $94^{\circ} \mathrm{C}$ for $3 \mathrm{~min}, 94^{\circ} \mathrm{C}$ for 30 sec, $60^{\circ} \mathrm{C}$ for $30 \mathrm{sec}, 72^{\circ} \mathrm{C}$ for $30 \mathrm{sec}, 35$ cycles followed by $72^{\circ} \mathrm{C}$ for $5 \mathrm{~min}$. BACs were isolated and prepared using KB-100 Magnum plasmid kit (Genome Systems, MO) according to the manufacturer's protocol. FISH was performed by labeling CNR2 with Biotin-16-dUTP (Boeringer Mannheim) and CNRcon with Spectrum Orange dUTP (Vysis), and the chromosome 18 painting probe with rhodamine-110 (Perkin-Elmer). The biotinylated DNA label was detected with Cy5 conjugated to avidin (Amersham). The slides were counterstained with DAPI for chromosome identification.

\section{Generation of mouse ATM polyclonal antiserum}

A $\sim 1-k b$ segment of cDNA spanning from nucleotides 54856468 of the mouse ATM open reading frame was amplified by PCR using the sense primer 5'-GACAGTGAATTCATAAA CAGTGAAATTCTCC-3' and the antisense primer 5'-TGTG GAGAATTCTCTGTTTCTTAGACACTG-3' from the mouse Atm cDNA clone 15-1 (a generous gift from Y. Shiloh, Tel Aviv University, Israel). After amplification, the DNA was digested at the primer-encoded BamHI site (5' end) and a naturally occurring EcoRI site ( $3^{\prime}$ end) and subcloned into digested pGEX2-T (Pharmacia) in a carboxy-terminal fusion to the protein GST. After authentication of the construct by sequence analysis, the E. coli strain TOP-10 (Invitrogen) was transformed and the encoded GST/mouse ATM fusion protein (encoding mouse ATM amino acids 1832-2152) was expressed by adding isopropylthio$\beta$-D-galactoside (IPTG, final concentration $1.0 \mathrm{mM}$ ) to a culture of logarithmically growing cells cultured at $37^{\circ} \mathrm{C}$ in $\mathrm{LB}$ broth containing $50 \mu \mathrm{g} / \mathrm{mL}$ ampicillin. The expressed fusion protein was found to be produced in an insoluble form; hence inclusion bodies were isolated by repeated rounds of sonication and centrifugation in extraction buffer $(150 \mathrm{mM}$ Tris $\mathrm{HCl}$ at $\mathrm{pH} 7.5,5$ mM EDTA, 1\% Triton X-100).

Lofstrand Laboratories (Gaithersburg, MD) performed all ani- mal housing and manipulation. Briefly, three adult New Zealand White rabbits were immunized with $100 \mu \mathrm{g}$ of the outlined inclusion body preparation suspended in Freund's complete adjuvant and boosted every 3 wk with $50 \mu \mathrm{g}$ of fusion protein suspended in Freund's incomplete adjuvant. Positive immunoreactivity against mouse ATM, as judged by immunoblot analysis using SDS extracts from wild-type and $\mathrm{Atm}^{-/-}$mouse testis and immunofluorescence microscopy assays, was observed in the serum of one of the immunized rabbits after the third boost. This serum, designated pAb $855 \mathrm{~m}$, was used for immunohistochemistry.

\section{Electrophoresis and immunoblotting}

Where indicated, cultured cells were harvested by scraping the culture dishes, collected by centrifugation, and washed extensively in cold $\left(4^{\circ} \mathrm{C}\right) \mathrm{PBS}$. SDS extracts were formed by adding $100-200 \mu \mathrm{L}$ of SDS solubilization solution (125 mM Tris- $\mathrm{HCl}$ at $\mathrm{pH} 7.5,5 \mathrm{mM}$ EDTA, 1\% SDS) to the cell pellet, placing it in a boiling water bath for $5 \mathrm{~min}$ and briefly sonicating. Cell fractionations were carried out by a modified hypotonic lysis protocol (Dignam et al. 1983), and all steps were carried out at $4^{\circ} \mathrm{C}$. Cells were washed and pelleted in PBS at $1850 \mathrm{~g}$ for $10 \mathrm{~min}$; the supernatant was removed and packed cell volume determined. The pellet was resuspended briefly in five packed cell volumes of hypotonic buffer (10 mM HEPES at $\mathrm{pH} 7.9,1.5 \mathrm{mM} \mathrm{MgCl}_{2}, 10$ $\mathrm{mM} \mathrm{KCl}, 0.2 \mathrm{mM} \mathrm{PMSF}$, and 0.5 mM DTT), and immediately centrifuged at $1850 \mathrm{~g}$ for $5 \mathrm{~min}$. The supernatant was decanted and cells were resuspended in three packed cell volumes of hypotonic buffer and placed on ice for $10 \mathrm{~min}$. Cells were lysed by 20 strokes in a Kontes Dounce homogenizer (B-type pestle), and lysis was confirmed by trypan blue staining. Lysates were centrifuged at $3300 \mathrm{~g}$ for $15 \mathrm{~min}$ to pellet nuclei. The cytosolic fraction was removed and the nuclear pellets were washed with three packed cell volumes of hypotonic buffer and centrifuged for $15 \mathrm{~min}$ at $3300 \mathrm{~g}$. Protein concentrations were determined using the BCA assay (Pierce). Before electrophoresis, extracts were diluted in an appropriate volume of $3 \times$ SDS sample buffer (150 mM Tris-HCl at $\mathrm{pH} 6.8,10 \% \beta$-mercaptoethanol, 20\% glycerol, $3 \%$ SDS, $0.01 \%$ bromophenol blue, $0.01 \%$ pyronin-Y) and boiled for $2 \mathrm{~min}$. SDS-PAGE, electrotransfer of the gels to nitrocellulose sheets, and antibody labeling were conducted as outlined using AM-9 antibody, which has been optimized for use in Western blotting but was not suitable for immunohistochemistry in the cell culture system described above (Barlow et al. 2000). Immunoreactive bands were visualized using Supersignal CR-HRP (Pierce) chemiluminescent substrate and recorded on X-ray film. Quantification of immunoblot signals was conducted by digitizing the immunoblot image (Agfa flat-bed scanner) and analyzed using NIH-Image software (version 1.62).

\section{Acknowledgments}

We thank Bobbie Miller for her expertise and assistance with the neural progenitor studies, Cara B. Allen, Linda Hinh, Andrea $\mathrm{Tu}$, and Linda R. Kitabayashi for help with immunohistochemistry and figure preparation, Kai Treuner and Tammy Lataxes for assistance with biochemical studies, Jamie T. Simon for figure preparation, and JoA Del Rio and Jennifer Greenhall for statistical assistance. K.D.B. is supported by the A-T Children's Project, F.H.G. by National Institutes of Health A606088, NO1NS-6-2348 and the Lookout Fund, and C.B. by the A-T Children's Project, the Searle Family Trust, and the Frederick B. Rentschler Developmental Chair.

The publication costs of this article were defrayed in part by 
payment of page charges. This article must therefore be hereby marked "advertisement" in accordance with 18 USC section 1734 solely to indicate this fact.

\section{References}

Barlow, C., Hirotsune, S., Paylor, R., Liyanage, M., Eckhaus, M., Collins, F., Shiloh, Y., Crawley, J., Ried, T., Tagle, D., et al. 1996. Atm deficient mice: A paradigm of ataxia-telangiectasia. Cell 86: 159-171.

Barlow, C., Brown, K., Deng, C.X., Tagle, D., and WynshawBoris, A. 1997. Atm selectively regulates distinct p53-dependent cell cycle checkpoint and apoptotic pathways. Nature Genet. 17: 453-456.

Barlow, C., Dennery, P.A., Shigenaga, M.K., Smith, M.A., Morrow, J.D., Roberts II, L.J., Wynshaw-Boris, A., and Levine, R.L. 1999. Loss of the ataxia-telangiectasia gene product causes oxidative damage in target organs. Proc. Natl. Acad. Sci. 96: 9915-9919.

Barlow, C., Ribaut-Barassin, C., Zwingman, T.A., Pope, A.J., Brown, K.D., Owens, J.W., Larson, D., Harrington, E.A., Haeberle, A.M., Mariani, J., et al. 2000. ATM is a cytoplasmic protein in mouse brain required to prevent lysosomal accumulation. Proc. Natl. Acad. Sci. 97: 871-876.

Brodsky, M.H., Sekelsky, J.J., Tsang, G., Hawley, R.S., and Rubin, G.M. 2000. mus304 encodes a novel DNA damage checkpoint protein required during Drosophila development. Genes \& Dev. 14: 666-678.

Brown, K., Ziv, Y., Sadanandan, S., Chessa, L., Collins, F., Shiloh, Y., and Tagle, D. 1997. The ataxia-telangiectasia gene product, a constitutively expressed nuclear protein that is not up-regulated following genome damage. Proc. Natl. Acad. Sci. 94: 1840-1845.

Brown, K., Barlow, C., and Wynshaw-Boris, A. 1999. Multiple ATM-dependent pathways-an explanation for pleiotropy. Am. J. Hum. Genet. 64: 46-50.

Caston, J., Devulder, B., Jouen, F., Lalonde, R., DelhayeBouchaud, N., and Mariani, J. 1999. Role of an enriched environment on the restoration of behavioral deficits in Lurcher mutant mice. Dev. Psychobiol. 35: 291-303.

Chong, M.J., Murray, M.R., Gosink, E.C., Russell, H.R., Srinivasan, A., Kapsetaki, M., Korsmeyer, S.J., and McKinnon, P.J. 2000. Atm and Bax cooperate in ionizing radiation-induced apoptosis in the central nervous system. Proc. Natl. Acad. Sci. 97: 889-894.

Cortez, D., Wang, Y., Qin, J., and Elledge, S.J. 1999. Requirement of ATM-dependent phosphorylation of brcal in the DNA damage response to double-strand breaks. Science 286: $1162-1166$.

Dignam, J.D., Martin, P.L., Shastry, B.S., and Roeder, R.G. 1983. Eukaryotic gene transcription with purified components. Methods Enzymol. 101: 582-598.

Frank, K.M., Sekiguchi, J.M., Seidl, K.J., Swat, W., Rathbun, G.A., Cheng, H.L., Davidson, L., Kangaloo, L., and Alt, F.W. 1998. Late embryonic lethality and impaired V(D)J recombination in mice lacking DNA ligase IV. Nature 396: 173-177.

Gage, F.H. 2000. Mammalian neural stem cells. Science 287: $1433-1438$.

Gao, Y., Sun, Y., Frank, K.M., Dikkes, P., Fujiwara, Y., Seidl, K.J., Sekiguchi, J.M., Rathbun, G.A., Swat, W., Wang, J., et al. 1998. A critical role for DNA end-joining proteins in both lymphogenesis and neurogenesis. Cell 95: 891-902.

Gao, Y., Ferguson, D.O., Xie, W., Manis, J.P., Sekiguchi, J., Frank, K.M., Chaudhuri, J., Horner, J., DePinho, R.A., and Alt, F.W. 2000. Interplay of p53 and DNA-repair protein
XRCC4 in tumorigenesis, genomic stability and development. Nature 404: 897-900.

Gatei, M., Young, D., Cerosaletti, K.M., Desai-Mehta, A., Spring, K., Kozlov, S., Lavin, M.F., Gatti, R.A., Concannon, P., and Khanna, K. 2000. ATM-dependent phosphorylation of nibrin in response to radiation exposure. Nature Genet. 25: 115-119.

Gatti, R.A. 1998. Ataxia-telangiectasia. McGraw-Hill, New York, NY.

Gu, Y., Sekiguchi, J., Gao, Y., Dikkes, P., Frank, K., Ferguson, D., Hasty, P., Chun, J., and Alt, F.W. 2000. Defective embryonic neurogenesis in Ku-deficient but not DNA-dependent protein kinase catalytic subunit-deficient mice. Proc. Natl. Acad. Sci. 97: 2668-2673.

Haber, J.E. 1998. The many interfaces of Mre11. Cell 95: 583586.

$$
\text { 829-832. }
$$

Herzog, K.H., Chong, M.J., Kapsetaki, M., Morgan, J.I., and McKinnon, P.J. 1998. Requirement for Atm in ionizing radiation-induced cell death in the developing central nervous system. Science 280: 1089-1091.

Kempermann, G., Brandon, E.P., and Gage, F.H. 1998. Environmental stimulation of $129 / \mathrm{SvJ}$ mice causes increased cell proliferation and neurogenesis in the adult dentate gyrus. Curr. Biol. 8: 939-942.

Kuhn, H.G., Winkler, J., Kempermann, G., Thal, L.J., and Gage, F.H. 1997. Epidermal growth factor and fibroblast growth factor-2 have different effects on neural progenitors in the adult rat brain. J. Neurosci. 17: 5820-5829.

Lakin, N., Weber, P., Stankovic, T., Rottinghaus, S., Taylor, A., and Jackson, S. 1996. Analysis of the ATM protein in wildtype and ataxia telangiectasia cells. Oncogene 13:27072716.

Lee, Y., Barnes, D.E., Lindahl, T., and McKinnon, P.J. 2000. Defective neurogenesis resulting from DNA ligase IV deficiency requires Atm. Genes \& Dev. 14: 2576-2580.

Lim, D.S., Kim, S.T., Xu, B., Maser, R.S., Lin, J., Petrini, J.H., and Kastan, M.B. 2000. ATM phosphorylates p95/nbs1 in an Sphase checkpoint pathway. Nature 404: 613-617.

Liyanage, M., Coleman, A., du Manoir, S., Veldman, T., McCormack, S., Dickson, R.B., Barlow, C., Wynshaw-Boris, A., Janz, S., Wienberg, J., et al. 1996. Multicolour spectral karyotyping of mouse chromosomes. Nature Genet. 14: 312-315.

Liyanage, M., Weaver, Z., Barlow, C., Coleman, A., Pankratz, D.G., Anderson, S., Wynshaw-Boris, A., and Ried, T. 2000. Abnormal rearrangement within the alpha/delta $\mathrm{T}$-cell receptor locus in lymphomas from Atm-deficient mice. Blood 96: $1940-1946$.

Palmer, T.D., Takahashi, J., and Gage, F.H. 1997. The adult rat hippocampus contains primordial neural stem cells. Mol. Cell Neurosci. 8: 389-404.

Paull, T.T. and Gellert, M. 1998. The $3^{\prime}$ to $5^{\prime}$ exonuclease activity of Mre 11 facilitates repair of DNA double-strand breaks. Mol. Cell 1: 969-979.

- 1999. Nbs1 potentiates ATP-driven DNA unwinding and endonuclease cleavage by the Mre11/Rad50 complex. Genes \& Dev. 13: 1276-1288.

Petrini, J.H. 2000. The Mre11 complex and ATM: Collaborating to navigate S phase. Curr. Opin. Cell Biol. 12: 293-296.

Ray, J. and Gage, F. 1999. Modern techniques in neuroscience research. Springer-Verlag, Berlin, Germany.

Rotman, G. and Shiloh, Y. 1998. ATM: From gene to function. Hum. Mol. Genet. 7: 1555-1563.

Savitsky, K., Sfez, S., Tagle, D.A., Ziv, Y., Sartiel, A., Collins, F.S., Shiloh, Y., and Rotman, G. 1995a. The complete se- 
Allen et al.

quence of the coding region of the ATM gene reveals similarity to cell cycle regulators in different species. Hum. Mol. Genet. 4: 2025-2032.

Savitsky, K., Bar-Shira, A., Gilad, S., Rotman, G., Ziv, Y., Vanagaite, L., Tagle, D.A., Smith, S., Uziel, T., Sfez, S., et al. 1995b. A single ataxia-telangiectasia gene with a product similar to PI-3 kinase. Science 268: 1749-1753.

Stewart, G.S., Maser, R.S., Stankovic, T., Bressan, D.A., Kaplan, M.I., Jaspers, N.G., Raams, A., Byrd, P.J., Petrini, J.H., and Taylor, A.M. 1999. The DNA double-strand break repair gene hMRE11 is mutated in individuals with an ataxia-telangiectasia-like disorder. Cell 99: 577-587.

Sugino, H., Hamada, S., Yasuda, R., Tuji, A., Matsuda, Y., Fujita, M., and Yagi, T. 2000. Genomic organization of the family of CNR cadherin genes in mice and humans. Genomics 63: 7587.

Threadgill, D.W., Yee, D., Matin, A., Nadeau, J.H., and Magnuson, T. 1997. Genealogy of the 129 inbred strains: $129 / \mathrm{SvJ}$ is a contaminated inbred strain. Mamm. Genome 8: 390-393.

van Praag, H., Kempermann, G., and Gage, F.H. 1999. Running increases cell proliferation and neurogenesis in the adult mouse dentate gyrus. Nature Neurosci. 2: 266-270.

Wang, J.Y. 2000. Cancer. New link in a web of human genes. Nature 405: 404-405.

Watters, D., Khanna, K.K., Beamish, H., Birrell, G., Spring, K., Kedar, P., Gatei, M., Stenzel, D., Hobson, K., Kozlov, S., et al. 1997. Cellular localisation of the ataxia-telangiectasia (ATM) gene product and discrimination between mutated and normal forms. Oncogene 14: 1911-1921.

Wu, Q. and Maniatis, T. 1999. A striking organization of a large family of human neural cadherin-like cell adhesion genes. Cell 97: 779-790.

. 2000. Large exons encoding multiple ectodomains are a characteristic feature of protocadherin genes. Proc. Natl. Acad. Sci. 97: 3124-3129.

$\mathrm{Xu}$, Y., Ashley, T., Brainerd, E., Bronson, R., Meyn, M., and Baltimore, D. 1996. Targeted disruption of ATM leads to growth retardation, chromosomal fragmentation during meiosis, immune defects, and thymic lymphoma. Genes \& Dev. 10: 2411-2422. 


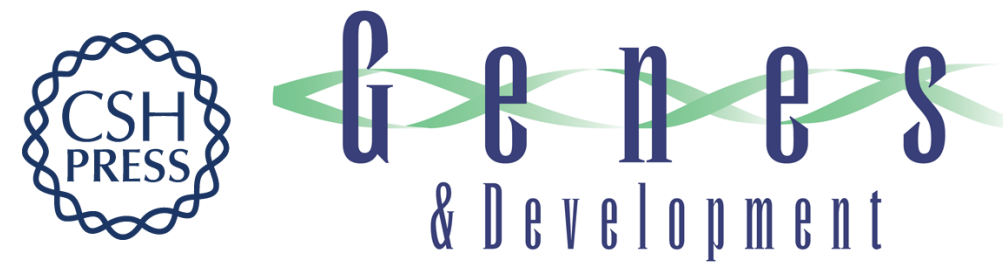

\section{Ataxia telangiectasia mutated is essential during adult neurogenesis}

Duane M. Allen, Henriette van Praag, Jasodhara Ray, et al.

Genes Dev. 2001, 15:

Access the most recent version at doi:10.1101/gad.869001

References This article cites 43 articles, 16 of which can be accessed free at: http://genesdev.cshlp.org/content/15/5/554.full.html\#ref-list-1

License

Email Alerting Receive free email alerts when new articles cite this article - sign up in the box at the top Service right corner of the article or click here.

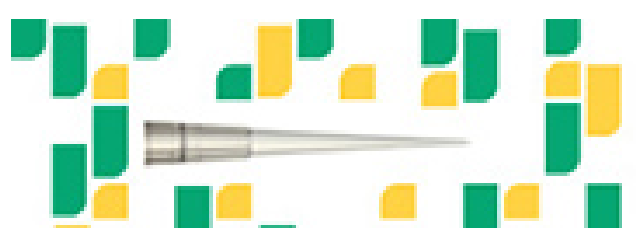

Focused on your science. 